\author{
ANNA BŁAŻEJCZYK ${ }^{1}$, JAROSŁAW BARANOWSKI ${ }^{2}$ \\ ${ }^{1}$ Bioklimatologia \\ Pracownia Bioklimatologii i Ergonomii Środowiskowej \\ Eukowska 17/55, 04-133 Warszawa \\ ${ }^{2}$ Instytut Geografii $i$ Przestrzennego Zagospodarowania PAN \\ Twarda 51/55, 00-818 Warszawa \\ E-mail: pracownia@bioklimatologia.pl \\ j.bar@twarda.pan.pl
}

\title{
WPŁYW ZMIAN KLIMATU NA ZMIANY ZACHOROWAŃ I ZGONÓW NA CHOROBY KLIMATOZALEŻNE W POLSCE W XXI WIEKU
}

\section{WPROWADZENIE}

Mimo ogromnego postępu medycyny zdrowie, zarówno pojedynczych osób, jak i całych społeczeństw, jest wciąz w znacznym stopniu uzależnione od różnorodnych czynników środowiskowych, w tym atmosferycznych. Oddziaływania te maja charakter bezpośredni i pośredni. Do bezpośrednich zaliczamy oddziaływania na organizm człowieka pojedynczych elementów klimatu i zjawisk pogodowych (KOZŁOWSKA-SZCZESNA i współaut. 2004, BŁAŻEJCZYK i KOZŁOWSKA-SZCZESNA 2008). Pośrednie oddziaływania klimatu na zdrowie człowieka uwidaczniaja się przez postępujaca urbanizację, problemy $z$ zaopatrzeniem w wodę pitna oraz choroby i infekcje przenoszone droga pokarmowa i wektorowo (CONFALONIERI i współaut. 2007).

Wskazując pożądane mechanizmy adaptacji do postępujacych zmian środowiska życia człowieka należy uwzględnić nie tylko zmiany klimatu, ale także czynniki środowiskowe i społeczno-ekonomiczne oddziałujące na sektor zdrowia (Ryc. 1).

Podejmowane sa liczne badania majace na celu określenie, jak obserwowane współcześnie zmiany klimatu moga wpłynąć na stan zdrowia społeczeństw w poszczególnych krajach i w skali globalnej (HAINES i współaut. 2006; Gosling i współaut. 2007, 2009; PATERSON i współaut. 2014; EBI 2015). W latach 2009-2012 w ramach projektu KLIMADA powstał dwuczęśsiowy raport Ocena skutków możliwych zmian klimatu dla zdrowia człowieka (BŁAżEJCZYK i współaut. 2011,
2012). Wnioski $z$ tych badań posłużyły do opracowania przez Ministerstwo Środowiska w 2013 r. dokumentu Strategiczny plan adaptacji dla sektorów i obszarów wrażliwych na zmiany klimatu do roku 2020 z perspektywa do roku 2030.

W celu uzupełnienia luk w wiedzy o regionalnym zróżnicowaniu relacji pomiędzy warunkami klimatycznymi a występowaniem chorób klimatozależnych w latach 2012-2015 realizowany był projekt badawczy NCN Nr 2011/01/B/ST10/06972 pt. Ocena wpływu zmian klimatu na stan zdrowia społeczeństwa $w$ różnych regionach Polski oraz prognoza do roku 2100. Pełne wyniki projektu zostały opublikowane w książce Wpływ klimatu na stan zdrowia $w$ Polsce: stan aktualny oraz prognoza do 2100 roku (BŁAŻEJCZYK i współaut. 2015) oraz w publikacjach cząstkowych (BŁAŻEJCZYK A. i współaut. 2018, BŁAŻEJCZYK i współaut. 2020). Celem obecnego opracowania jest przedstawienie tej części wyników, które dotycza prognozy zmian zachorowań na niektóre choroby klimatozależne i zgonów do końca XXI w.

\section{ODDZIAEYWANIA KLIMATU NA ZDROWIE}

Czynniki meteorologiczne i ogólne cechy klimatu danego regionu działaja na człowieka jako bodziec, określany mianem stresu pogodowego (FERS 1995, KALKSTEIN 1998, MCGREGOR 2001, KUCHCIK 2003, KOZŁOWSKA-SZCZESNA i BŁAŻEJCZYK 2010). Poszczególne 


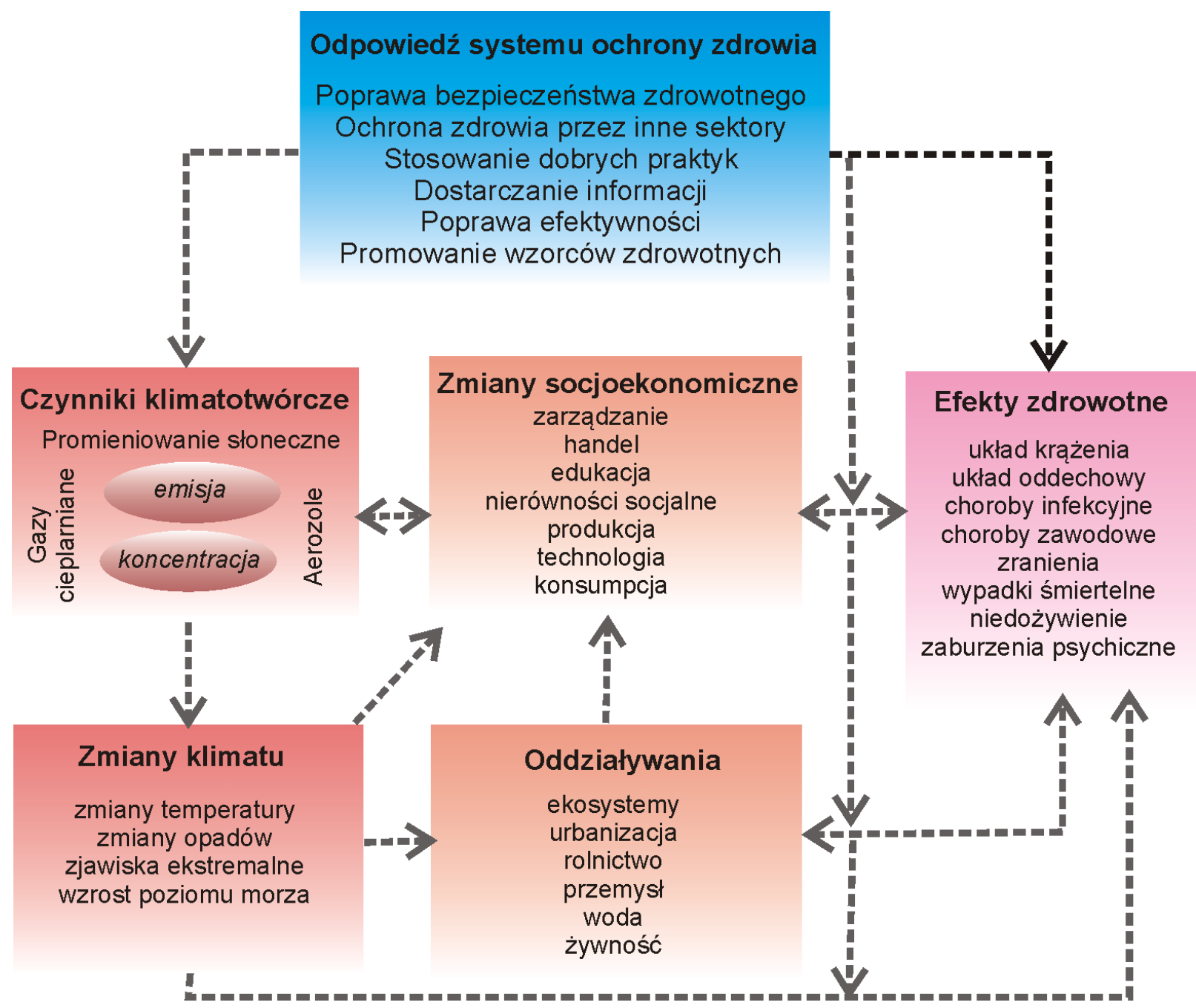

Ryc. 1. Powiązania pomiędzy zmianami klimatu i ich przyczynami a zmianami w ekosystemach, stanem zdrowia i rozwojem socjoekonomicznym (wg MenNe i współaut. 2008, zmieniona).

elementy meteorologiczne w istotny sposób wpływaja na procesy fizjologiczne zachodzace w organizmie człowieka. Najsilniejsze oddziaływania maja miejsce $\mathrm{w}$ przypadku promieniowania słonecznego, temperatury i wilgotności powietrza, ciśnienia atmosferycznego oraz prędkości wiatru.

Niezależnie od strefy klimatycznej, autorzy licznych badań zwracaja uwage na duży wzrost liczby zgonów i zachorowań podczas fal goraca (KUCHCIK i BŁAŻEJCZYK 2001; DESSAI 2002; DIAZ i współaut. 2006; KUCHCIK 2006, 2017). Ryzyko choroby lub zgonu wzrasta, gdy mamy jednocześnie do czynienia $z$ dużym natężeniem promieniowania słonecznego i wysoką wilgotnością powietrza (MATZARAKIS i MAYER 1991; BŁAŻEJCZYK 2000, 2004; BEAŻEJCZYK i współaut. 2000; LASCHEWSKI i JENDRITZKY 2002; BEAŻEJCZYK i MCGREGOR 2007). Dla umiarkowanych i wysokich szerokości geograficznych specyficzne sa także komplikacje zdrowotne zwiąane $z$ niskimi wartościami temperatury powietrza, a szczególnie $z$ falami mrozów (ENG i MERCER 1998, Gyllerup 1998, KeAtinge i DoNALDSON 1998, KUCHCIK 2017).

W przypadku promieniowania słonecznego największe znaczenie dla zdrowia człowieka ma promieniowanie nadfioletowe (UV). Nadmierne dawki tego promieniowania moga powodować choroby skóry, oczu i zaburzenia układu immunologicznego (LUCAS i współaut. 2006, CONFALONIERI i współaut. 2007, BŁAŻEJCZYK i BŁAŻEJCZYK 2012a). Do najgroźniejszych należy uszkodzenie DNA jadra komórek skóry prowadzące do rozwoju nowotworów skóry, w tym również czerniaka szczególnie groźnego dla życia człowieka (LITYŃSKA i współaut. 2001). Coraz częstszym problemem sa także fotoalergie (KIEĆ-ŚSIERCZYŃSKA i KRECISZ 2008).

W przypadku bodźców termiczno-wilgotnościowych ważne sa obciażenia układu termoregulacyjnego i krwionośnego człowieka. Procesy adaptacji organizmu do różnych i często zmieniających się warunków termicz- 
Tabela 1. Oddziaływania środowiskowe i zdrowotne poszczególnych elementów klimatu.

\begin{tabular}{|c|c|c|c|}
\hline Element klimatu & Miara & Oddziaływanie środowiskowe & Oddziaływanie zdrowotne \\
\hline \multirow[t]{2}{*}{$\begin{array}{l}\text { promieniowanie sło- } \\
\text { neczne }\end{array}$} & $\begin{array}{l}\text { wzrost dopływu } \\
\text { UV }\end{array}$ & działanie bakteriobójcze & $\begin{array}{l}\text { wzrost zachorowań na nowotwory } \\
\text { skóry }\end{array}$ \\
\hline & $\begin{array}{l}\text { intensywna in- } \\
\text { solacja }\end{array}$ & stymulowanie wegetacji roślin & udar słoneczny, wypadki drogowe \\
\hline \multirow[t]{4}{*}{ temperatura powietrza } & fale upałów & $\begin{array}{l}\text { wzrost stężeń ozonu troposfery- } \\
\text { cznego }\end{array}$ & $\begin{array}{l}\text { wzrost zgonów, udary cieplne, od- } \\
\text { wodnienie, astma, zaburzenia kra- } \\
\text { żenia }\end{array}$ \\
\hline & fale zimna & wzrost PM10 $\mathrm{i} \mathrm{SO}_{2}$ & $\begin{array}{l}\text { wychłodzenie, infekcje układu odde- } \\
\text { chowego, odmrożenia, urazy, astma }\end{array}$ \\
\hline & gorace lata & $\begin{array}{l}\text { rozwój kleszczy, zanieczyszczenie } \\
\text { wody }\end{array}$ & $\begin{array}{l}\text { zatrucia pokarmowe } \\
\text { choroby odkleszczowe }\end{array}$ \\
\hline & ciepłe zimy & przyspieszenie sezonu pylenia & $\begin{array}{l}\text { nasilenie alergii i astmy, wczesne } \\
\text { infekcje kleszczowe }\end{array}$ \\
\hline \multirow[t]{2}{*}{ opad atmosferyczny } & $\begin{array}{l}\text { intensywne } \\
\text { opady }\end{array}$ & $\begin{array}{l}\text { powodzie, zanieczyszczenie ujęć } \\
\text { wody pitnej, pogorszenie warun- } \\
\text { ków drogowych }\end{array}$ & $\begin{array}{l}\text { zatrucia pokarmowe, utonięcia, wy- } \\
\text { padki drogowe }\end{array}$ \\
\hline & susze & $\begin{array}{l}\text { zapylenie powietrza, alergeny } \\
\text { roślinne }\end{array}$ & astma, alergie \\
\hline \multirow[t]{2}{*}{ wiatr } & cisze & stagnacja zanieczyszczeń & $\begin{array}{l}\text { astma, infekcje układu oddechowe- } \\
\text { go }\end{array}$ \\
\hline & silne wiatry & zniszczenia budynków & $\begin{array}{l}\text { wypadki śmiertelne, zaburzenia } \\
\text { układu nerwowego }\end{array}$ \\
\hline $\begin{array}{l}\text { ciśnienie atmosferycz- } \\
\text { ne }\end{array}$ & $\begin{array}{l}\text { wartość ciśnie- } \\
\text { nia, zmiany } \\
\text { ciśnienia }\end{array}$ & brak danych & $\begin{array}{l}\text { zaburzenia układu nerwowego, za- } \\
\text { burzenia układu krązenia }\end{array}$ \\
\hline
\end{tabular}

wg BŁAŻEJCZYK i współaut. 2015

nych otoczenia (co jest typowe dla klimatu Polski) powodują znaczne obciażenia tych układów. Obciażenia te zmniejszaja efektywność układu odpornościowego, powodując częste zapadanie na choroby infekcyjne prowadząc do różnorodnych dysfunkcji organizmu, a nawet do śmierci. Grupami szczególnie wrażliwymi na wpływ temperatury sa osoby starsze i małe dzieci, u których łatwo dochodzi do zaburzeń gospodarki cieplnej organizmu, oraz osoby ze specyficznymi schorzeniami (LAAIDI i współaut. 2006, WHO 2009).

Zmiany $w$ stanie zdrowia człowieka powodowane sa także pośrednio przez inne elementy środowiska, kształtowane przez ogólne lub miejscowe warunki klimatyczne. Do tej grupy przyczyn chorób można zaliczyć: urbanizację i związany $z$ nią wzrost zanieczyszczeń powietrza, zaopatrzenie w wodę i jej stan sanitarny, zmiany w populacji i rozmieszczeniu owadów przenoszących choroby. Na przykład, specyfika radiacyjno-termiczna miast sprawia, że w ich centralnych częściach, o wysokiej zabudowie i przewadze powierzchni sztucznych, temperatura odczuwalna jest średnio o około $5^{\circ} \mathrm{C}$ wyższa niż na obszarach otaczających miasto (BŁAŻEJCZYK i KUNERT 2006, BŁAŻEJCZYK i współaut. 2014). Jednocześnie, miasta cechuja się zwiększonym poziomem zanieczyszczeń powietrza. W badaniach projektu EuroHEAT, które objęły 9 miast europejskich, stwierdzono 10,5\% wzrost zgonów w dniach upalnych. Gdy wysokiej temperaturze towarzyszył wysoki poziom ozonu, wzrost liczby zgonów był wyższy aż o około 16\%, a gdy podwyższony był poziom pyłu zawieszonego (PM10) wzrost ten wynosił 14\% (WHO 2009).

Bezpośrednią przyczyna chorób układu pokarmowego sa bakterie, wirusy lub drobnoustroje patogenne znajdujace się w pożywieniu lub wodzie pitnej. Należy podkreślić, że warunki atmosferyczne, a zwłaszcza podwyższona temperatura powietrza, sa czynnikiem sprzyjajacym rozwojowi lub namnażaniu się patogenów. W Polsce najpowszechniejsza choroba przenoszona droga pokarmowa jest salmonelloza, a do zakażeń dochodzi najczęściej w ciepłej porze roku (BŁAŻEJCZYK i współaut. 2011, BŁAŻEJCZYK i BŁAŻEJCZYK 2012b).

Do tzw. chorób wektorowych w Polsce należą choroby przenoszone przez kleszcze. Do najczęstszych i najgroźniejszych chorób odkleszczowych należą: kleszczowe zapalenie mózgu (KZM) i borelioza. Wzrost liczby zachorowań na KZM i boreliozę wiąże się $z$ obserwowanymi zmianami w środowisku, w tym zmianami klimatycznymi. Ocieplanie się 
klimatu odpowiedzialne jest za wydłużenie okresu żerowania kleszczy, który trwa obecnie od lutego/marca do listopada (LINDGREN i JAENSON 2006).

Zestawienie oddziaływań środowiskowych i zdrowotnych poszczególnych elementów i cech klimatu zawiera Tabela 1.

\section{MATERIAEY I METODY BADAŃ}

W badaniach oparto się na dwóch grupach danych: epidemiologicznych (o zachorowaniach $i$ zgonach $z$ powodu niektórych chorób klimatozależnych) i klimatycznych (o radiacyjnych, termicznych, wilgotnościowych, wiatrowych i opadowych cechach klimatu). Pod pojęciem "choroby klimatozależne" należy rozumieć sytuacje zdrowotne, które sa w mniejszym lub większym stopniu zależne od czynników klimatycznych. Największym problemem w badaniu zmienności chorób klimatozależnych jest brak ogólnodostępnych baz danych dotyczacych infekcji dróg oddechowych. Ogólnopolskie bazy danych regionalnych dotycza tylko wybranych chorób (nowotwory, zatrucia, choroby zakaźne). Wykorzystano także ogólnopolska bazę danych o zgonach zwiazanych $z$ zaburzeniami układu krażenia i układu oddechowego.

Ciagi obserwacyjne dotyczace chorób klimatozależnych zostały zaczerpnięte $z$ różnych źródeł: Roczników Statystycznych Polski, GUS; raportów Państwowego Zakładu Higieny (PZH) Choroby zakaźne $i$ zatrucia $w$ Polsce; $z$ Krajowego Rejestru Nowotworów przy Centrum Onkologii; $z$ bazy danych o umieralności Światowej Organizacji Zdrowia (WHO Mortality Data Base)

$Z$ uwagi na specyfikę informacji epidemiologicznych zestawiono je $z$ wartościami średnimi obszarowymi elementów meteorologicznych. Oparto się na wspólnym dla 26 wytypowanych stacji meteorologicznych okresie 1973-2014, a dane o rozdzielczości do- bowej zaczerpnięto $Z$ serwisu NOAA (dane $Z$ satelitów meteorologicznych). Analizie poddano różne charakterystyki klimatyczne.

Prognozy podstawowych elementów klimatu (całkowite promieniowanie słoneczne, temperatura i wilgotność powietrza, prędkość wiatru, opady atmosferyczne) zaczerpnięto $z$ programu METEONORM 7. Program ten wykorzystuje do obliczeń symulacyjnych wiazke 18 modeli klimatu przygotowana na potrzeby 4 raportu IPCC (ang. Intergovernmental Panel on Climate Change) (MEEHL i współaut. 2007). Symulacje wykonano dla 40 stacji meteorologicznych w Polsce dla kolejnych dziesięcioleci XXI w., uwzględniając trzy scenariusze emisji $\mathrm{CO}_{2}$ (ang. Special Report on Emissions Scenarios,

SRES): B1, A1B i A2 (NAKICENOVIC i współaut. 2000). Scenariusz B1 zakłada stosunkowo niewielki wzrost emisji dwutlenku węgla (do 600 ppm w 2100 r.) i wynikający $z$ tego wzrost temperatury powietrza rzędu $1,8^{\circ} \mathrm{C}$. Scenariusz A2 opiera się na założeniu, że wzrost emisji $\mathrm{CO}_{2}$ będzie duży (do $1250 \mathrm{ppm})$, powodując wzrost temperatury powietrza o $3,4^{\circ} \mathrm{C}$. Scenariusz A1B jest określany jako najbardziej prawdopodobny. Zakłada on wzrost emisji dwutlenku węgla do $850 \mathrm{ppm}$ i temperatury powietrza o $2,8^{\circ} \mathrm{C}$.

W prognozowaniu zmian stanu zdrowia wykorzystano schemat zaproponowany przez Goslinga i współaut. (2009). Składa się on z dwóch etapów (Ryc. 2). W etapie pierwszym poszukiwano modeli statystycznych relacji pomiędzy niezależnymi zmiennymi klimatycznymi a zależnymi zmiennymi dotyczacymi zachorowalności i umieralności. Ten etap badań opiera się na zbiorach danych historycznych. W drugim etapie, korzystajac $z$ istniejacych projekcji zmian klimatu, dokonano prognozy na przyszłość. Przygotowano w tym celu zestaw niezależnych zmiennych klimatycznych i na podstawie opracowanych

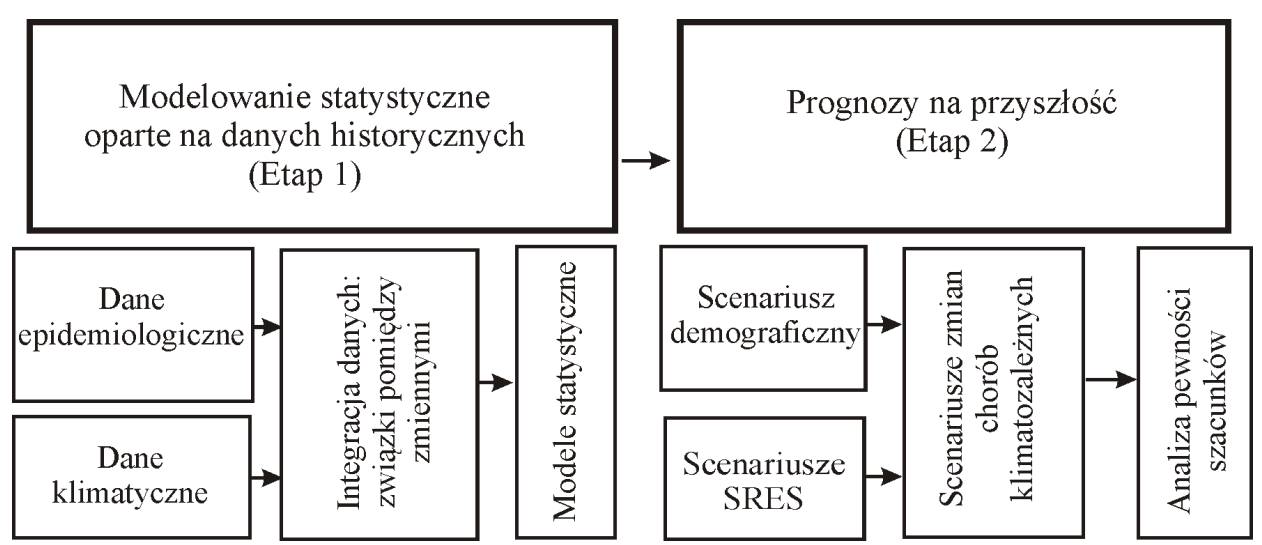

Ryc. 2. Schemat badań dotyczacych prognozy zachorowań i zgonów na choroby klimatozależne (wg GoSLING i współaut. 2009, zmieniona). 
w pierwszym etapie modeli statystycznych obliczono możliwe zmiany zachorowań i zgonów na choroby klimatozależne do końca XXI w. Do obliczenia możliwej liczby zachorowań i zgonów wykorzystano także prognozy dotyczace zmian demograficznych.

\section{WIELOLETNIE ZMIANY CECH KLIMATU W POLSCE}

W przedziale 1973-2014 miał miejsce stopniowy wzrost temperatury powietrza, zwłaszcza w okresie letnim, wynoszacy $0,043^{\circ} \mathrm{C} /$ rok. W przypadku średniej rocznej słaby trend wyniósł $0,015^{\circ} \mathrm{C} /$ rok. Duża zmienność $z$ roku na rok średniej temperatury miesięcy zimowych sprawia, że nie zaznacza się żaden istotny statystycznie trend zmian. Istotne statystycznie były wzrosty temperatury maksymalnej oraz liczby dni gorących i bardzo goracych. Dla osób starszych, chorych na astmę i osób z zaburzeniami układu krażenia uciażliwe sa sytuacje zwiazane $z$ wysoka temperatura i wilgotnościa powietrza. W badanym okresie nastapił bardzo wyraźny wzrost takich sytuacji, o 0,24 dnia na każdy rok kalendarzowy.

Obserwowany wzrost temperatury powietrza i częstości dni parnych ma także odzwierciedlenie w zmianach warunków biotermicznych. Do ich scharakteryzowania wykorzystano uniwersalny wskaźnik obciażeń cieplnych (ang. universal thermal climate index, UTCI) (BŁAŻEJCZYK i współaut. 2010) (Tabela 2). W badanym okresie liczba dni $z$ dużym stresem zimna (DSZ) zmniejszała się z około 55 na poczatku, do około 30 pod koniec okresu. Liczba dni $z$ dużym stresem goraca (DSC) ma tendencję wzrostowa, z 5 do około 10 dni.

Wiatr w istotny sposób wpływa na stan zdrowia. Wiatr silny $\left(>8 \mathrm{~m} \cdot \mathrm{s}^{-1}\right)$ ma działanie bodźcowe i przyczynia się do nasilenia stresu zimna przy niskiej, a stresu ciepła przy wysokiej temperaturze powietrza. Wiatr słaby $\left(<1 \mathrm{~m} \cdot \mathrm{s}^{-1}\right)$ sprzyja stagnacji zanieczyszczeń powietrza, co niekorzystnie wpływa na układ oddechowy. W badanym wieloleciu

Tabela 2. Kategorie obciażeń cieplnych wg wskaźnika UTCI.

\begin{tabular}{|c|c|c|}
\hline \multicolumn{2}{|l|}{ Kategoria obciążeń cieplnych } & \multirow{2}{*}{$\begin{array}{l}\text { Zakres } \\
\left({ }^{\circ} \mathrm{C}\right)\end{array}$} \\
\hline Opis & Skrót & \\
\hline Bardzo silny stres zimna & \multirow{2}{*}{ DSZ } & $<-27$ \\
\hline Silny stres zimna & & $-27-13$ \\
\hline Umiarkowany stres zimna & USZ & $-13-0$ \\
\hline Mały stres zimna & MSZ & $0-9$ \\
\hline Brak obciążeń cieplnych & 0 & $9-26$ \\
\hline Umiarkowany stres ciepła & USC & $26-32$ \\
\hline Silny stres ciepła & \multirow{2}{*}{ DSC } & $32-38$ \\
\hline Bardzo silny stres ciepła & & $>38$ \\
\hline
\end{tabular}

liczba dni $z$ wiatrem słabym zmniejszała się istotnie o około 0,44 dnia/rok w miesiacach zimowych i o 0,08 dnia/rok w miesiacach letnich.

Opady atmosferyczne (ich suma i częstość występowania) wpływają na warunki rozwoju owadów (komary, kleszcze), zwiększając ryzyko tzw. chorób wektorowych. Analiza statystyczna wieloletniej zmienności opadów wykazała słaby trend wzrostowy sum opadów (o $1,1 \mathrm{~mm} /$ rok) i liczby dni $\mathrm{Z}$ opadem (o 0,25 dnia/rok).

$\mathrm{Na}$ przestrzeni 40 badanych lat $z$ roku na rok zmieniała się także liczba zachorowań i zgonów na choroby klimatozależne. W Europie Środkowej, w tym w Polsce, choroby układu krążenia są główną przyczyną zgonów. W czasie zmian pogody obserwuje się nasilenie objawów choroby niedokrwiennej serca, podwyższenie częstości zawałów mięśnia sercowego i zwiększenie wahań ciśnienia tętniczego krwi. Hospitalizacje chorych $z$ powodu tzw. ostrych zdarzeń kardiologicznych sa zdecydowanie częstsze w półroczu chłodnym niż ciepłym. W Polsce roczna liczba zgonów $z$ powodu chorób serca wyraźnie wzrosła w okresie 1973-1993. W ostatnich latach zmiany $z$ roku na rok sa niewielkie. Odwrotny przebieg wieloletni maja zgony $z$ powodu chorób układu oddechowego, tzn. spadek do roku 1993, a następnie stopniowy wzrost (BŁAŻEJCZYK i współaut. 2015).

W przypadku rocznej liczby zachorowań na grype miały miejsce częste zmiany. Zaznaczaja się lata ze zwiększona i zmniejszona liczba zachorowań, co wydaje się być związane ze zmianami warunków pogodowych, przy czym zwiększona liczbę zachorowań obserwuje się od listopada do marca. Zakażenia borelioza następują najczęściej w miesiącach letnich, co wiąże się $z$ aktywnościa biologiczna kleszczy. Rejestry zachorowań obejmuja okres po 2003 r. i wykazuja wyraźny wzrost.

Bardzo wyraźny, stopniowy wzrost jest także widoczny w przypadku zachorowań na nowotwory skóry, w tym czerniaka. Wiąże się to prawdopodobnie ze stopniowym powiększaniem się tzw. dziury ozonowej, skutkującym zwiększonym dopływem kancerogennego promieniowania nadfioletowego (BŁAŻEJCZYK i BŁAŻEJCZYK 2012b).

Wpływ warunków termicznych na stan zdrowia i umieralność jest przedmiotem licznych badań w wielu krajach świata. Szczegółowe badania prowadzone w Polsce przez BŁAŻEJCZYKA i współaut. (2015) pokazuja, że w dniach, w których wystąpił duży stres ciepła ryzyko zgonu jest większe o $20 \%$ niż w dniach $z$ warunkami termoneutralnymi. Analogicznie, w dniach $z$ bardzo dużym i ekstremalnym stresem ciepła ryzyko zgonu 
Tabela 3. Statystyczne modele regresji pomiędzy różnymi zmiennymi klimatycznymi a zachorowalnością i umieralnością na choroby klimatozależne.

\begin{tabular}{|c|c|c|}
\hline $\begin{array}{l}\text { Średni błąd bez- } \\
\text { względny }\end{array}$ & $\begin{array}{l}\text { Współczynnik de- } \\
\text { terminacji }\end{array}$ & $\begin{array}{l}\text { Poziom ufności } \\
(\%)\end{array}$ \\
\hline \multicolumn{3}{|l|}{ Nowotwory skóry: zachorowania/100 tys. } \\
\hline -60,84+0,05311·Kglob_lato & 54,88 & 95 \\
\hline \multicolumn{3}{|l|}{ Borelioza: zachorowania/100 tys. } \\
\hline 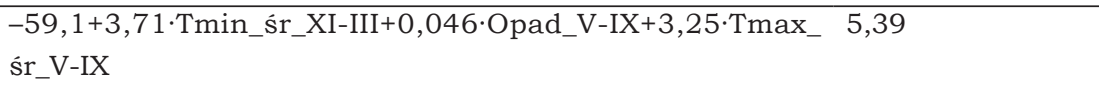 & 40,96 & 85 \\
\hline \multicolumn{3}{|l|}{ Grypa: zachorowania/100 tys. } \\
\hline $\begin{array}{l}\text { 18178,5-1598,87·Tśr_zima+1807,19·Tmin_śr_zima- 2094,56 } \\
\text {-1799,69·Tmax_śr_zima-12,26·Tmax<0_zima }\end{array}$ & 25,42 & 95 \\
\hline \multicolumn{3}{|l|}{ Zgony z przyczyn układu krążenia/100 tys. } \\
\hline $\begin{array}{l}\text { 325,55+4,25·Tmin<-10-1,63·Tmax }>25-2,11 \cdot \text { Parno+12,87·T- } 49,57 \\
\text { min_śr-93,29·Tmax_śr }+143,88 \cdot T s ́ r\end{array}$ & 22,79 & 85 \\
\hline Zgony z przyczyn układu oddechowego/100 & & \\
\hline 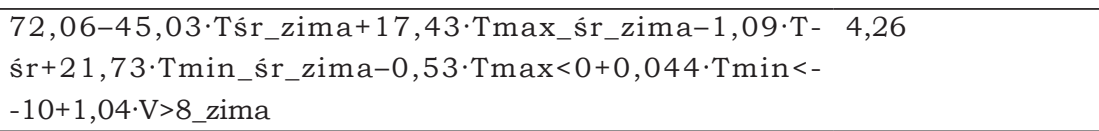 & 48,10 & 95 \\
\hline
\end{tabular}

Kglob_lato - suma całkowitego promieniowania słonecznego dla lata, Tśr - średnia roczna temperatura powietrza, Tśr_zima - średnia temperatura dla okresu XII-II, Tmax_śr - średnia roczna temperatura maksymalna, Tmax_śr_VIX - średnia temperatura maksymalna dla okresu V-IX, Tmax_śr_zima - średnia temperatura maksymalna dla okresu XII-II, Tmin_śr_zima - średnia temperatura minimalna dla okresu XII-II, Tmin_śr_XI-III - średnia tempe-

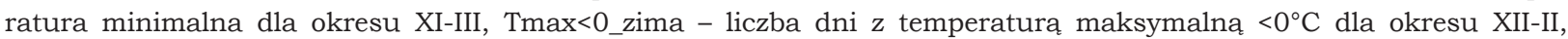
Tmax $>25$ - roczna liczba dni $z$ temperatura maksymalna $>25^{\circ} \mathrm{C}$, Tmax $<0$ - roczna liczba dni $z$ temperatura maksymalna $<0^{\circ} \mathrm{C}$, Tmin $<-10$ - roczna liczba dni $z$ temperatura minimalna $<-10^{\circ} \mathrm{C}$, Opad_ V-IX - suma opadu dla okresu V-IX, Parno - roczna liczba dni parnych, V>8_zima - liczba dni z prędkością wiatru $>8 \mathrm{~m} / \mathrm{s}$.

jest większe odpowiednio o $52 \%$ i $102 \%$. W odniesieniu do dni ze stresem zimna ma miejsce wzrost ryzyka o: $10 \%$ - przy stresie umiarkowanym, $21 \%-\mathrm{w}$ dniach $\mathrm{z}$ dużym stresem zimna, $30 \%$ - podczas bardzo dużego stresu zimna i o $34 \%$ - w warunkach ekstremalnego stresu zimna.

\section{MIARY ODDZIAEYWANIA KLIMATU NA CHOROBY KLIMATOZALEŻNE}

Wskaźniki ilościowe określające oddziaływanie klimatu na stan zdrowia człowieka można podzielić na dwie grupy: proste i zespołowe. Do grupy prostych wskaźników klimatycznych zalicza się podstawowe charakterystyki meteorologiczne (patrz Tabela 1):

- w odniesieniu do promieniowania słonecznego: natężenie promieniowania ( $\mathrm{w}$ tym promieniowania UV), sumy nasłonecznienia;

- w odniesieniu do warunków termiczno-wilgotnościowych: średnia, maksymalna i minimalna temperatura powietrza, amplituda temperatury, wilgotność względna powietrza i ciśnienie pary wodnej, stany parności;

- w odniesieniu do opadów atmosferycznych: opad maksymalny, sumy opadu, liczba dni $z$ opadem;
- w odniesieniu do wiatru: średnia i maksymalna prędkość, liczba dni z ciszą i wiatrem silnym;

- w odniesieniu do ciśnienia atmosferycznego: ciśnienie niskie i wysokie, zmiany śróddobowe i międzydobowe.

Przeprowadzone badania wykazały, że jedynie w odniesieniu do zachorowań na nowotwory skóry można zastosować prosta miarę klimatyczna, tzn. sumę promieniowania całkowitego w okresie letnim. W przypadku innych chorób klimatozależnych informacje epidemiologiczne wskazuja, że na zapadalność ma wpływ złożony zespół charakterystyk klimatu. W celu określenia możliwego oddziaływania klimatu na stan zdrowia społeczeństwa, opracowano zespół 30 wskaźników klimatycznych. Wyniki regresji wielokrotnej pozwoliły na wytypowanie tych wskaźników, które najsilniej wpływały na dana chorobę lub prowadzily do zgonów. Pozwoliło to na opracowanie modeli statystycznych oddziaływania poszczególnych zmiennych klimatycznych na wielkość zachorowań i/lub zgonów na poszczególne choroby klimatozależne (Tabela 3).

Odmienny sposób modelowania zastosowano $\mathrm{w}$ przypadku zgonów będących skut- 
kiem dużego lub umiarkowanego stresu ciepła i zimna. Przeanalizowano codzienne rejestry zgonów w 9 miastach Polski w latach 1993-2001. Rejestry te zestawiono $z$ codziennymi wartościami wskaźnika UTCI. Codzienne liczby zgonów zaklasyfikowano do poszczególnych kategorii tego wskaźnika, a dla każdej $z$ wyróżnionych kategorii UTCI obliczono średnia liczbę zarejestrowanych zgonów. Liczbę tę odnoszono do liczby mieszkańców danego miasta. Uzyskano w ten sposób dobowy, standaryzowany wskaźnik umieralności na 100 tys. mieszkańców. Szczegółowe algorytmy do wyznaczenia liczby zgonów, które moga być zwiąane $z$ poszczególnymi kategoriami stresu zimna (ZSZ) i stresu goraca (ZSC), maja następujacca postać:

- dla stresu zimna (USZ+DSZ):

$\mathrm{ZSZ}=(2,59 \cdot$ populacja/ 100 tys. $\mathrm{x}$ liczba dni $z$ USZ) + (2,89·populacja/100 tys. $x$ liczba dni $z$ DSZ),

- dla stresu ciepła (USC+DSC):

$\mathrm{ZSC}=(2,58 \cdot$ populacja $/ 100$ tys. $\mathrm{x}$ liczba dni $z$ USC) + (2,87·populacja/100 tys. $x$ liczba dni $z$ DSC).

\section{PROGNOZA ZMIAN WARUNKÓW KLIMATYCZNYCH W POLSCE DO ROKU 2100}

Cechą charakterystyczna klimatu jest jego zmienność w czasie. Za przyczynę tych zmian uznaje się dwie grupy czynników: naturalne i antropogeniczne. Na obecnym etapie wiedzy o zmianach klimatu przyjmuje się, że w jego kształtowaniu w przyszłości znacząca rolę odgrywać będa obie te grupy, ze wskazaniem na czynniki antropogeniczne.

Prognozy zmian średniej rocznej temperatury powietrza wskazuja na systematyczny jej wzrost w kolejnych dziesięcioleciach XXI w. Trend taki obserwowany jest we wszystkich trzech scenariuszach SRES, a najwyższe wartości temperatury będa obserwowane w ostatniej dekadzie XXI w. W dekadzie 2021-2030 wartość średniej rocznej temperatury powietrza wyniesie $\mathrm{w}$ uwzględnionych scenariuszach od 8,0 do $9,2^{\circ} \mathrm{C}$. Największy wzrost średniej rocznej temperatury powietrza w okresie kolejnych siedmiu dekad przewidywany jest w scenariuszu A2 i wyniesie ponad $2,5^{\circ} \mathrm{C}$. Najłagodniejszy scenariusz (B1) przewiduje wzrost o $1,1^{\circ} \mathrm{C}$, a scenariusz A1B o $2,1^{\circ} \mathrm{C}$ (Ryc. 3).

Jeszcze bardziej wyraziste zmiany warunków termicznych widoczne są w przypadku temperatury maksymalnej i minimalnej. W kolejnych dekadach największe zmiany przewiduje scenariusz A2, według którego w dekadzie 2091-2100 temperatura maksymalna będzie o $2,6^{\circ} \mathrm{C}$ wyższa niż obecnie. Najła- godniejsze zmiany temperatury maksymalnej prognozowane sa w scenariuszu B1 i wyniosa one $1,0^{\circ} \mathrm{C}$. W przypadku temperatury minimalnej, w XXI w. wzrost może wynieść w skrajnym scenariuszu A2 aż $2,9^{\circ} \mathrm{C}$, a w najbardziej łagodnym B1 $1,2^{\circ} \mathrm{C}$.

Wartości średniej prędkości wiatru w kolejnych dekadach XXI w. nie będą ulegać większym zmianom. Średnia roczna prędkość wiatru wyniesie pod koniec wieku około 3,6 $\mathrm{m} \cdot \mathrm{s}^{-1}$. Również $\mathrm{w}$ okresie letnim i zimowym, $\mathrm{w}$ żadnym ze scenariuszy nie sa prognozowane wyraźne zmiany prędkości wiatru.

Zgodnie ze scenariuszem B1 w XXI w. będą wyraźnie wzrastały roczne sumy opadu, od $633 \mathrm{~mm}$ w dekadzie 2021-2030 do $645 \mathrm{~mm}$ u schyłku stulecia. W scenariuszu A1B, w pierwszych trzech dekadach wieku może nastapić niewielki wzrost opadów $\mathrm{z}$ 632 do $638 \mathrm{~mm}$ rocznie, w kolejnych dwu dekadach będa się utrzymywać na poziomie $635 \mathrm{~mm}$, a następnie, aż do końca XXI w., ustabilizuja się na poziomie $630 \mathrm{~mm}$. Zupełnie inną prognozę sum opadów atmosferycznych podaje scenariusz A2, według którego będzie następował spadek wielkości opadów począwszy od dekady 2031-2040. Pod koniec stulecia średni opad może wynieść 616 $\mathrm{mm}$, czyli o $30 \mathrm{~mm}$ mniej niż $\mathrm{w}$ scenariuszu B1.

Wykonane symulacje wskazuja, że w kolejnych dziesięcioleciach XXI w. średnie roczne wartości UTCI będa systematycznie wzrastały. W zależności od przyjętego scenariusza, pod koniec obecnego wieku moga one wzrosnać do $8,8^{\circ} \mathrm{C}$ (według scenariusza B1) do $10,6^{\circ} \mathrm{C}$ (scenariusz A2). Stopniowy wzrost jest także przewidywany w przypadku maksymalnych wartości UTCI, które w ostatniej dekadzie XXI w. osiagna od $41,2^{\circ} \mathrm{C}$ (scenariusza B1) do $43,6^{\circ} \mathrm{C}$ (scenariusz A2) (Ryc. 4).

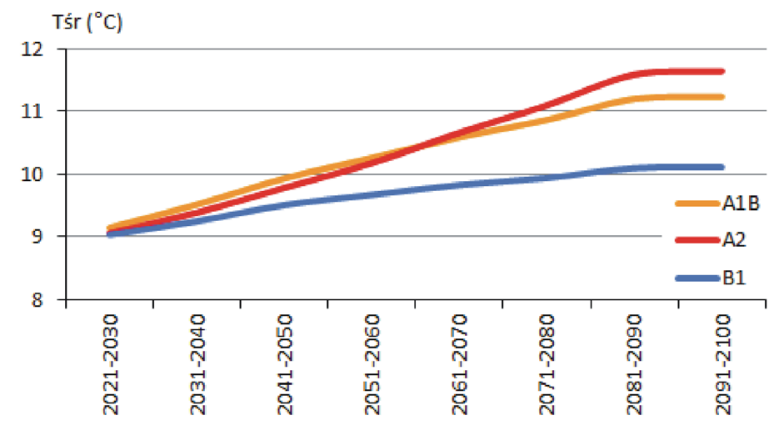

Ryc. 3. Średnie roczne wartości temperatury powietrza w Polsce w kolejnych dekadach XXI w. prognozowane według różnych scenariuszy SRES (A1B, A2, B1) (wg BŁAŻEJCZYK i współaut. 2015, zmieniona). 


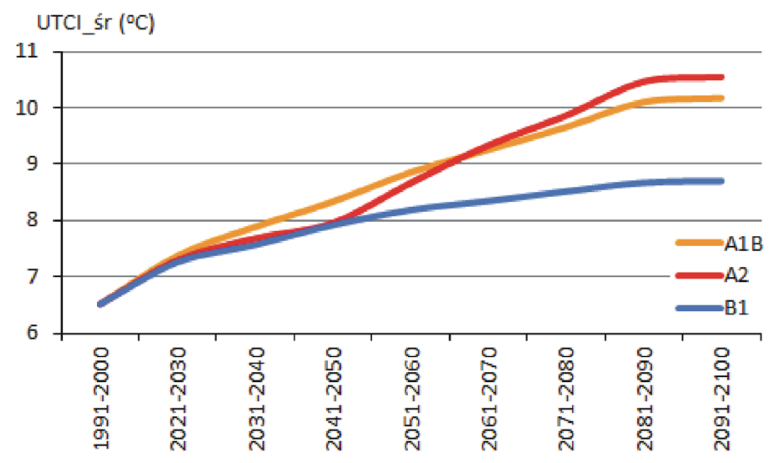

Ryc. 4. Średnie roczne (UTCI_śr) wartości wskaźnika UTCI w kolejnych dekadach XXI w. w odniesieniu do wartości obserwowanych w latach 1991-2000, prognozowane według różnych scenariuszy SRES (A1B, A2, B1) (wg BŁAŻEJCZYK i współaut. 2015, zmieniona).

\section{PROGNOZA ZACHOROWAŃ I ZGONÓW NA CHOROBY KLIMATOZALEŻNE DO ROKU 2100}

Równania regresji zamieszczone $\mathrm{w}$ Tabeli 3 posłużyły do opracowania prognozy zachorowań i zgonów na choroby klimatozależne do 2100 r. w poszczególnych województwach. Poza standaryzowana liczba zachorowań i zgonów (na 100 tys. mieszkańców), obliczono także jakich, wyrażonych w procentach, zmian zapadalności i umieralności należy oczekiwać w różnych okresach XXI w.: w latach 2021-2040, 2051-2070 i 2081-2100.

\section{NOWOTWORY SKÓRY}

Liczba zachorowań zwiększy się z około 26 przypadków na 100 tys. mieszkańców, jaki był obserwowany $\mathrm{w}$ pierwszej dekadzie XXI w., do blisko 29 przypadków w dekadzie ostatniej. Scenariusz B1 zakłada szybkie tempo wzrostu pomiędzy dekada 2021-2030 i 2051-2060. Scenariusz A1B zakłada systematyczny wzrost zachorowań do roku 2080, a następnie ich stabilizację. Natomiast scenariusz A2 przyjmuje, że największego tempa wzrostu liczby zachorowań należy się spodziewać $\mathrm{w}$ drugiej połowie XXI w. (Ryc. 5). Tak więc, zapadalność na nowotwory skóry zwiększy się od $8,7 \%$ (scenariusz B1) do $10 \%$ (scenariusze A1B i A2).

W porównaniu ze stanem obecnym największa liczba zachorowań nadal będzie notowana w województwach: opolskim i wielkopolskim. Istotnych zmian, $\mathrm{w}$ porównaniu ze stanem współczesnym, należy się spodziewać w województwach: zachodniopomorskim, kujawsko-pomorskim, podkarpackim i dolnośląskim (Ryc. 6).

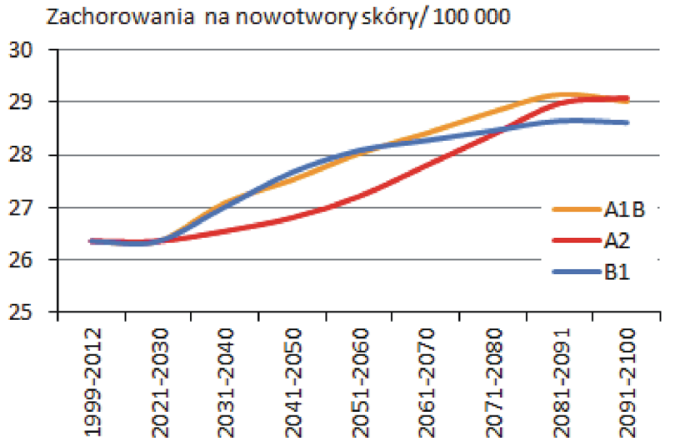

Ryc. 5. Standaryzowany wskaźnik zachorowalności na nowotwory skóry w Polsce w kolejnych dekadach XXI w. przewidywana przy uwzględnieniu różnych scenariuszy SRES (A1B, A2, B1) (wg BŁAŻEJCZYK i współaut. 2015, zmieniona).

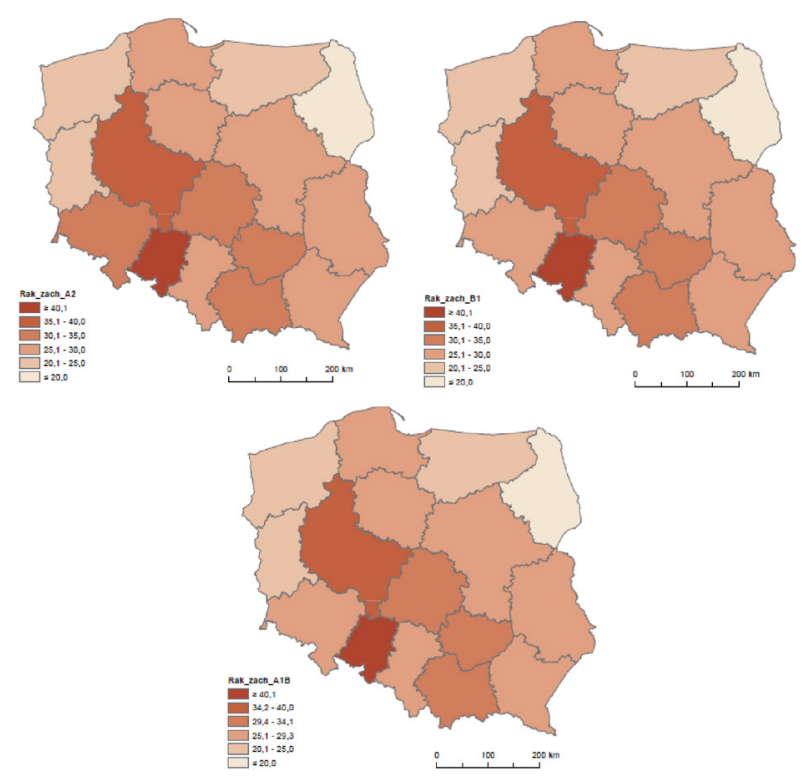

Ryc. 6. Wskaźniki zachorowalności (na 100 tys. mieszkańców) na nowotwory skóry ogółem prognozowane na lata 2091-2100 przy zastosowaniu różnych scenariuszy SRES (A2, B1 i A1B), na tle zapadalności obserwowanej współcześnie (wg BŁAŻEJCZYK i współaut. 2015, zmieniona).

\section{BORELIOZA}

Według scenariuszy A1B i A2 w ostatniej dekadzie XXI w. zapadalność na boreliozę może wzrosnać do 38-41 przypadków na 100 tys., to oznacza wzrost o 58-68\%. Nieco łagodniejszy wzrost zakłada scenariusz $\mathrm{B} 1, \mathrm{w}$ którym na koniec wieku jest prognozowany wzrost zachorowań do około 31 osób na 100 tys. (Ryc. 7).

Nadal najwięcej zachorowań będzie występować w województwach: podlaskim i warmińsko-mazurskim, jednak względny wzrost zapadalności będzie na tych ob- 


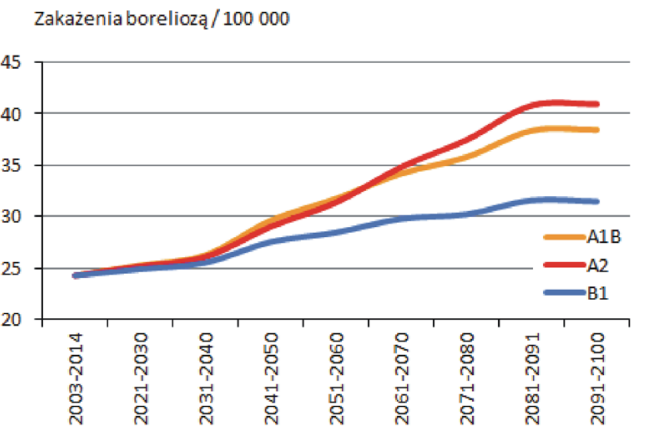

Ryc. 7. Standaryzowany wskaźnik zachorowalności na boreliozę w Polsce w kolejnych dekadach XXI w. przewidywany przy uwzględnieniu różnych scenariuszy SRES (A1B, A2, B1) (wg BŁAŻEJCZYK i współaut. 2015, zmieniona).

szarach stosunkowo niewielki (od 10 do $38 \%$ ). Największego wzrostu liczby zachorowań (od 60 do 214\%) trzeba natomiast oczekiwać w województwach: wielkopolskim, łódzkim, pomorskim i świętokrzyskim. Większych, od przeciętnego dla całej Polski, wzrostów zachorowań na boreliozę należy się spodziewać także w województwach: zachodniopomorskim, kujawsko-pomorskim, mazowieckim, lubelskim, świętokrzyskim i dolnośląskim (Ryc. 8).

\section{GRYPA}

Analizujac zachorowania na grype w odniesieniu do 100 tys. mieszkańców przewiduje się, że w skali Polski wskaźnik zachorowalności będzie się systematycznie obniżał w kolejnych dekadach XXI w. O ile obecnie wynosi on około 2450/100 tys., to w ostatniej dekadzie wieku spadnie do poziomu od 750 (scenariusz A2) do 1840 (scenariusz B1) (Ryc. 9). Tak więc spadek wskaźnika zachorowalności na grypę na koniec XXI w. może się wahać od około $22 \%$ do $68 \%$.

Wskaźnik zapadalności na grypę różni się pomiędzy województwami. W scenariuszu A1B zmiany te moga się wahać od $-15 \%$ (woj. śląskie) do $-96 \%$ (woj. lubuskie). W scenariuszu A2 zakres możliwych zmian wynosi od $-48 \%$ (woj. mazowieckie) do -94\% (woj. lubuskie). Najmniejsze zmiany zakłada scenariusz B1: od $-4 \%$ w Ślasskiem, do $-72 \%$ w Świętokrzyskiem (Ryc. 10).

\section{ZGONY Z PRZYCZYN CHORÓB UKŁADU KRAZŻENIA}

Klimatycznymi czynnikami stresogennymi, wpływajacymi na funkcjonowanie układu krążenia, sa niska i wysoka temperatura oraz wysoka wilgotność powietrza. Sce-

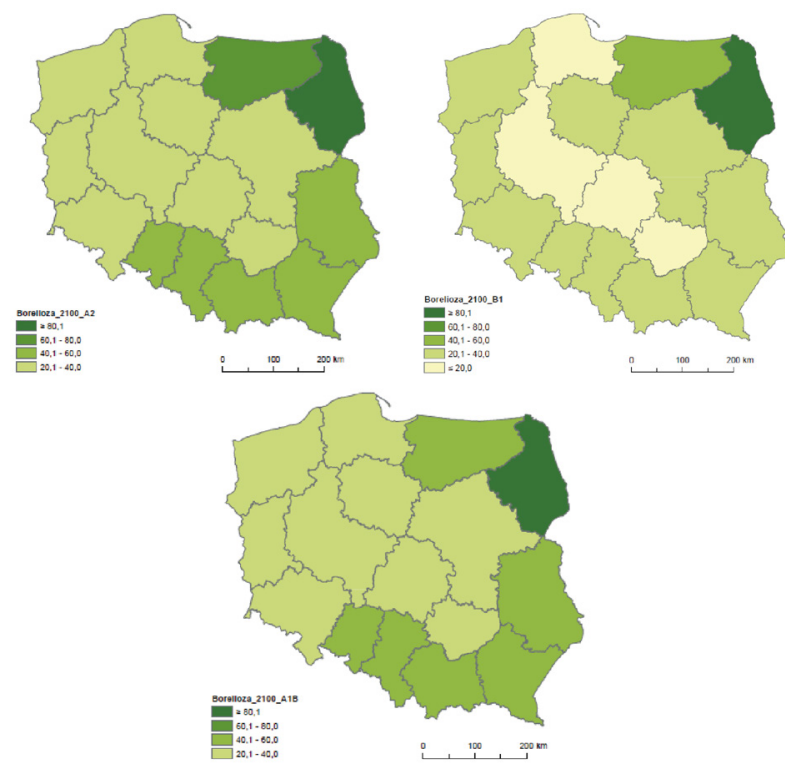

Ryc. 8. Wskaźniki zachorowalności (na 100 tys. mieszkańców) na boreliozę prognozowane na lata 2091-2100, przy zastosowaniu różnych scenariuszy SRES (A2, B1 i A1B), na tle zapadalności obserwowanej współcześnie (wg BŁAŻEJCZYK i współaut. 2015, zmieniona).

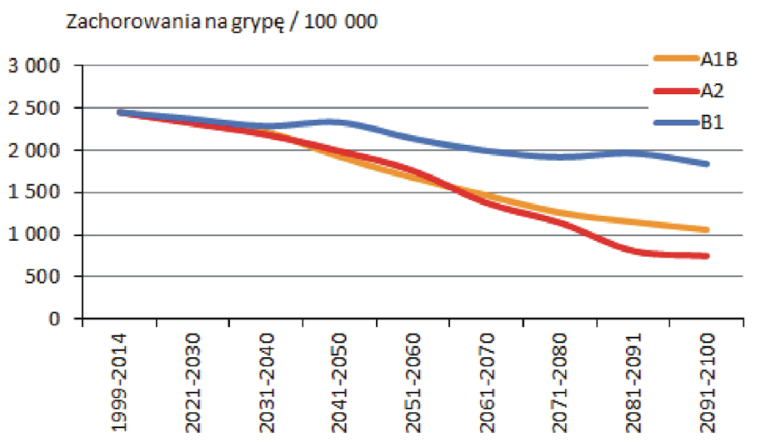

Ryc. 9. Standaryzowany wskaźnik zachorowalności na grypę w Polsce w kolejnych dekadach XXI w. przewidywany przy uwzględnieniu różnych scenariuszy SRES (A1B, A2, B1) (wg BŁAŻEJCZYK i współaut. 2015, zmieniona).

nariusze SRES zakładają wzrost wskaźnika umieralności. Według scenariuszy A1B i A2 wzrośnie on $z$ około 346 (na przełomie XX i XXI w.) do około 360 zgonów na 100 tys. mieszkańców w ostatnich dekadach XXI w. Scenariusz B2 zakłada łagodniejszy wzrost do około 355 na koniec wieku (Ryc. 11). W wartościach względnych oznacza to wzrost ryzyka zgonu rzędu 3-4\%.

W zdecydowanej większości województw tendencje zmian wskaźnika umieralności $\quad Z$ powodu chorób układu krążenia sa zgodne $z$ tendencja średnią dla Polski. Jednak 


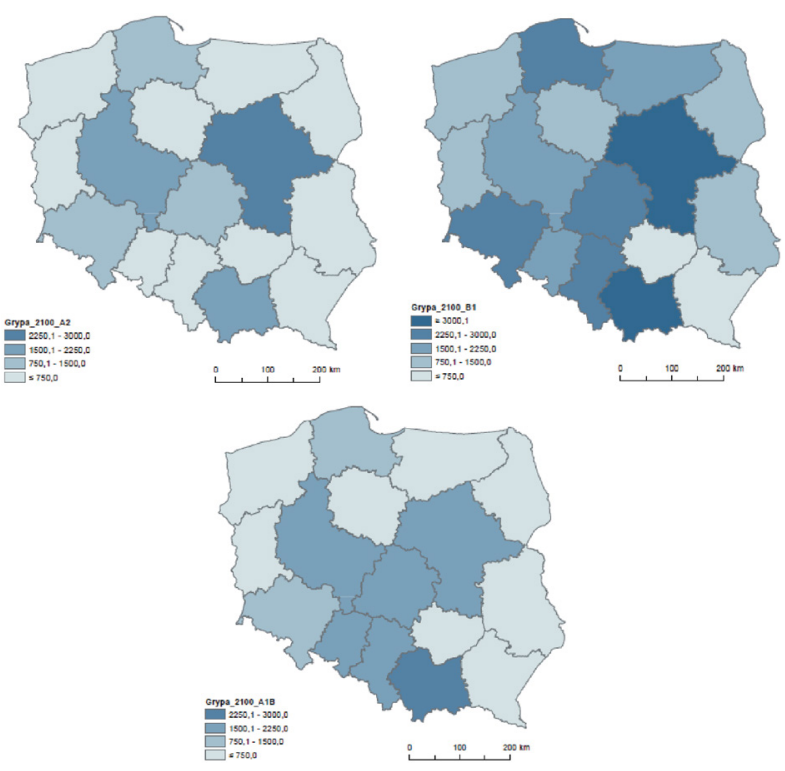

Ryc. 10. Wskaźniki zachorowalności (na 100 tys. mieszkańców) na grypę prognozowane dla lat 2091-2100, przy zastosowaniu różnych scenariuszy SRES (A2, B1 i A1B) na tle zapadalności obserwowanej współcześnie (wg BŁAŻEJCZYK i współaut. 2015, zmieniona).

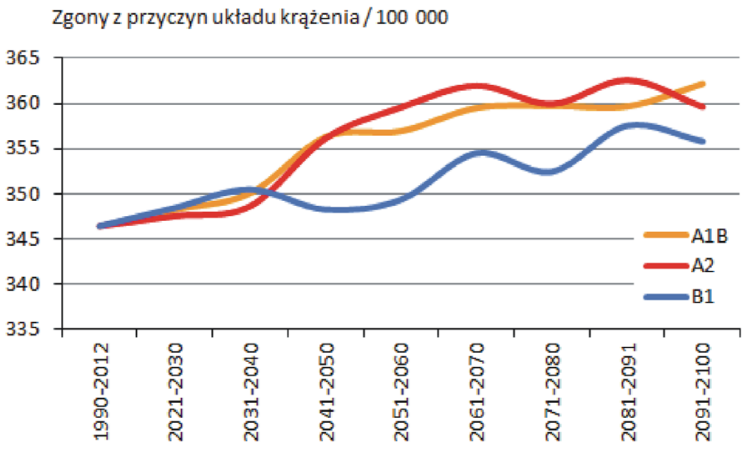

Ryc. 11. Standaryzowany wskaźnik umieralności z powodu dysfunkcji układu krażenia w Polsce w kolejnych dekadach XXI w. przewidywana przy uwzględnieniu różnych scenariuszy SRES (A1B, A2, B1) (wg BŁAŻEJCZYK i współaut. 2015, zmieniona).

dla województwa opolskiego scenariusze zakładają nie wzrost, a spadek wskaźnika umieralności od $1,5 \%$ do $7,6 \%$. Część scenariuszy przewiduje także nieznaczny spadek wskaźnika w województwach: dolnośląskim, ślaskim, małopolskim i podkarpackim. Znacznie większy niż średnio w Polsce wzrost wskaźnika umieralności $z$ powodu chorób układu krażenia (od 3 do 11\%) scenariusze SRES zakładaja w województwach: zachodniopomorskim (o 4-8\%), pomorskim,

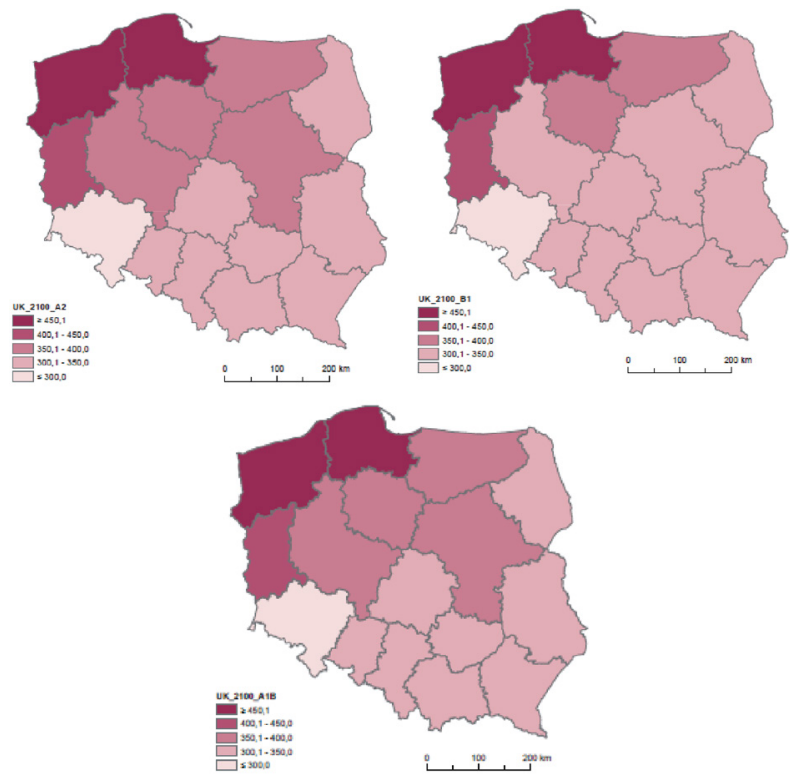

Ryc. 12. Umieralność (na 100 tys. mieszkańców) $z$ powodu chorób układu krążenia prognozowana na lata 2091-2100 przy zastosowaniu różnych scenariuszy SRES (A2, B1 i A1B) (wg BŁAŻEJCZYK i współaut. 2015, zmieniona).

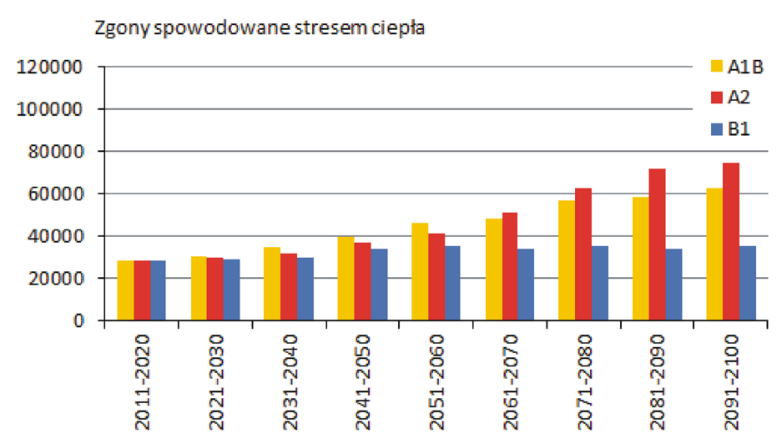

Ryc. 13. Przewidywana roczna liczba zgonów spowodowanych stresem ciepła w kolejnych dekadach XXI w. według różnych scenariuszy SRES (A1B, A2, B1) (wg BŁAŻEJCZYK i współaut. 2015, zmieniona).

lubuskim, wielkopolskim i kujawsko-pomorskim (Ryc. 12).

\section{ZGONY SPOWODOWANE STRESEM CIEPŁA}

Średnio, liczba zgonów spowodowanych stresem ciepła będzie wyraźnie wzrastała. Największy wzrost zakłada scenariusz A2, z obecnych 28 tys. osób, do blisko 75 tys. rocznie w ostatniej dekadzie XXI w. Scenariusz A1B przewiduje wzrost do około 63 tys., a scenariusz B1 - do 35,5 tys. rocznie (Ryc. 13). W wartościach względnych wzrost 


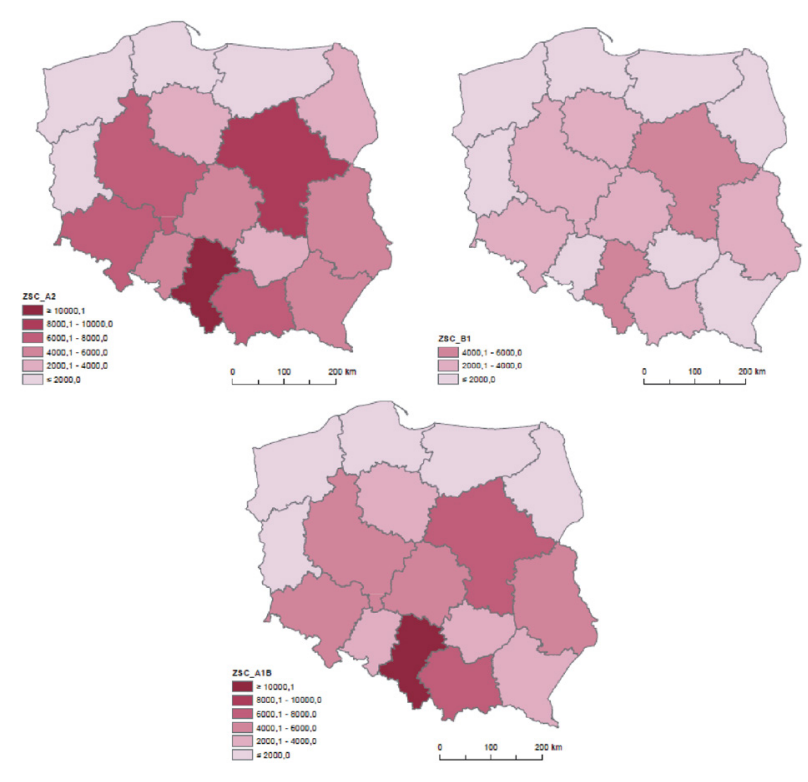

Ryc. 14. Liczba zgonów spowodowanych stresem ciepła (ZSC) prognozowana na lata 2091-2100 przy zastosowaniu różnych scenariuszy SRES (A2, B1 i A1B) (wg BŁAŻEJCZYK i współaut. 2015, zmieniona).

ten może zatem wynieść od $137 \%$ (B1) do $277 \%$ (A2).

Największego względnego wzrostu zgonów wywołanych stresem ciepła, rzędu 180460\%, można oczekiwać w województwie śląskim. Wyższe od średniej krajowej wzrosty liczby zgonów są zakładane także w województwach: kujawsko-pomorskim, łódzkim i dolnośląskim. Z kolei najmniejsze wzrosty sa przewidywane w zachodniopomorskim i wielkopolskim (Ryc. 14).

Biorac pod uwagę obserwowane współcześnie i przewidywane do końca XXI w. zmiany klimatu stwierdzono, że w kolejnych dekadach wieku ryzyko zachorowań i/lub zgonów (na 100 tys. mieszkańców) będzie się istotnie zmieniało. Tabela 4 zawiera zestawienie obliczonych tendencji zmian wybra- nych wskaźników zdrowotnych. Największy wzrost, rzędu $137-277 \%$, jest spodziewany w przypadku liczby zgonów spowodowanych stresem ciepła. O 22-68\% może także wzrosnać ryzyko zakażenia borelioza, a o 9-10\% wzrośnie ryzyko zachorowania na nowotwory skóry. W wyniku postępujących zmian klimatu zmniejszy się natomiast ryzyko zgonu $z$ przyczyn infekcji grypowych (o 23-68\%) i zgonów spowodowanych skutkami zdrowotnymi dużego stresu zimna (o 64-74\%).

\section{PROPOZYCJE DZIAŁAŃ ADAPTACYJNYCH SYSTEMU OCHRONY ZDROWIA}

Pożąane działania adaptacyjne można podzielić na dwie grupy: działania doraźne i długofalowe.

Działania doraźne to:

- wyposażenie placówek służby zdrowia $\mathrm{w}$ podstawowy sprzęt klimatyzacyjny w celu łagodzenia stresu goraca;

- zapewnienie odpowiedniej liczby przeszkolonego personelu medycznego do pomocy poszkodowanym przez zdarzenia pogodowe (w tym stres ciepła i stres zimna);

- odpowiednie zabezpieczenie placówek służby zdrowia w sezonowe środki zaopatrzenia medycznego, np. kompresy chłodzace i rozgrzewające, opatrunki hydrożelowe, koce termiczne, unieruchomienia (szyny, deski ortopedyczne), środki na oparzenia słoneczne, kołdry chłodzace, worki $z$ lodem, chłodne płyny, defibrylatory;

- właściwe zabezpieczenie stanowisk pracy narażonych na działanie czynników atmosferycznych przed ich negatywnymi skutkami.

Działania długofalowe:

- szkolenia personelu medycznego w kierunku poprawy diagnostyki i leczenia chorób klimatozależnych oraz przygotowanie i opracowanie programu kształcenia w zakresie wpływu czynników klimatycznych i zanieczyszczeń środowiska na zdrowie;

Tabela 4. Przewidywane zmiany wskaźników zachorowalności i umieralności na choroby klimatozależne w Polsce dla okresu 2081-2100.

\begin{tabular}{lll}
\hline Wskaźnik zdrowotny & Trend & Pewność szacunków \\
\hline umieralnośc z przyczyn układu krążenia & wzrost 3-4\% & umiarkowana \\
umieralność z przyczyn układu oddechowego & spadek 7-17\% & duża \\
zachorowalność na nowotwory skóry & wzrost 9-10\% & duża \\
zgony z powodu stresu ciepła & wzrost 137-277\% & duża \\
zgony z powodu stresu zimna & spadek 64-74\% & umiarkowana \\
zachorowalność na grypę & spadek 23-50\% & duża \\
zachorowalność na boreliozę & wzrost 22-68\% &
\end{tabular}

wg Błażejczyk i współaut. 2015 
- zwiększenie liczby laboratoriów diagnostycznych pozwalajacych na wczesne wykrywanie chorób odkleszczowych;

- modernizacja laboratoriów i placówek diagnostycznych pozwalających na wczesne wykrywanie problemów kardiologicznych; poprawa infrastruktury technicznej obiektów służby zdrowia (w tym wykonanie termoizolacji) w celu dostosowania do częstszych i intensywniejszych fal goraca;

- rozbudowa systemu monitorowania jakości powietrza i kontrola wdrażanych programów naprawczych;

prowadzenie systematycznego monitoringu $i$ stworzenie interaktywnego systemu rejestrowania i statystyki występowania chorób klimatozależnych;

- zapewnienie środków na prowadzenie naukowych badań epidemiologicznych i klimatyczno-fizjologicznych w celu lepszego poznania mechanizmów reakcji człowieka na bodźce klimatyczne;

- stworzenie efektywnego systemu profilaktyki zdrowotnej (badania okresowe, zachowanie w warunkach ekstremalnych zjawisk pogodowych, pierwsza pomoc przedmedyczna $\mathrm{w}$ takich sytuacjach).

$$
\text { Streszczenie }
$$

Klimat i jego zmiany wpływaja na stan zdrowia pojedynczych osób i całych społeczeństw. Problemy zdrowotne wywolywane czynnikami klimatycznymi sa określane jako choroby klimatozależne. W Polsce należa do nich infekcje dróg oddechowych, grypa, nowotwory skóry, borelioza i kleszczowe zapalenie mózgu, salmonelloza, problemy krażeniowe oraz zaburzenia układu termoregulacyjnego spowodowane stresem goraca lub stresem zimna. Na podstawie danych epidemiologicznych i klimatycznych za lata 1973-2014 opracowano modele statystyczne wpływu różnych cech klimatu na choroby klimatozależne. W drugim etapie badań dokonano, na podstawie tych modeli, prognozy zachorowań i zgonów na choroby klimatozależne w kolejnych dekadach XXI w. Stwierdzono istotne statystycznie wzrosty takich chorób jak: nowotwory skóry, borelioza czy zgony $z$ przyczyn kardiologicznych i związane ze stresem goraca. Trendy spadkowe wykazuja natomiast infekcje grypowe i zgony z powodu chorób układu oddechowego.

\section{LITERATURA}

BŁAŻEJCZYK A., BŁAŻEJCZYK K., BARANOWSKI J., KUCHCIK M., 2018. Heat stress mortality and desired adaptation responses of healthcare system in Poland. Int. J. Biometeorol. 62, 307-318.

BŁAŻEJCZYK K., 2000. Influence of extremal heat waves on man. Instytut Geografii UJ, Prace Geograficzne, 108, 101-108.

BŁAŻEJCZYK K., 2004. Bioklimatyczne uwarunkowania rekreacji $i$ turystyki $w$ Polsce. Prace Geograficzne IGiPZ PAN, 192.

BŁAŻEJCZYK K., KunERT A., 2006. Differentiation of bioclimatic conditions of urban areas (the case of Poland). [W:] 6th International Conference on Urban Climate, June 12-16, 2006, Göteborg, Sweden, Preprints, 213-216.
BŁAŻEJCZYK K., MCGREGOR G., 2007. Warunki biotermiczne a umieralność $w$ wybranych aglomeracjach europejskich. Przegląd Geograficzny $79,401-423$.

BŁAŻEJCZYK K., KOZŁOWSKA-SZCZĘSNA T., 2008. Klimat a zdrowie. Kosmos 57, 269-280.

BŁAŻEJCZYK K, BŁAŻEJCZYK A., 2012a. Changes in $U V$ radiation intensity and their possible impact on skin cancer in Poland. Geographia Polonica 85, 57-64.

BŁAŻEJCZYK K, BŁAŻEJCZYK A., 2012b. Środowiskowe $i$ klimatyczne uwarunkowania zatruć pokarmowych - stan aktualny $i$ prognoza do roku 2100. [W:] Cywilizacja a środowisko wyzwania $i$ dylematy. KANTOWICZ E., ROGE-WiŚNIEWSKA M. (red.). Wydział Geografii i Studiów Regionalnych UW, 55-65.

BŁAŻEJCZYK K., BARANOWSKI J., PISARCZYK S. SZPOT M., 2000. Influence of the human heat balance on respiratory and circulatory diseases. [W:] Biometeorology and urban climatology at the turn of millennium. DE DEAR R. J., Kalma J. D., OKe T. R., Auliciems A. (red.). Selected papers from the Conference ICBICUC'99 (Sydney, 8-12 Nov. 1999). World Meteorological Organization, Genewa, 107-11.

BŁAŻEJCZYK K., BRÖDE P., FIALA D., HAVENITH G., HOLMER I., JENDRITZKY G., KAMPMANN B., 2010. UTCI - Nowy wskaźnik oceny obciażeń cieplnych człowieka. Przegląd Geograficzny 82, 49-71.

BŁAŻEJCZYK K., PIOTROWICZ K., KUCHCIK M., MYsZKOWSKA D., SKOTAK K., KUNERT A., IDZIKOWSKA D. 2011. Ocena skutków możliwych zmian klimatu dla zdrowia człowieka, cz. 1. Raport dla Instytutu Ochrony Srodowiska - PIB w ramach projektu „Opracowanie i wdrożenie Strategicznego Planu Adaptacji dla sektorów i obszarów wrażliwych na zmiany klimatu KLIMADA".

BŁAŻEJCZYK K., SKOTAK K., BŁAŻEJCZYK A., PIOTROWICZ K., MYSZKOWSKA D., SZMYD J., 2012. Ocena skutków możliwych zmian klimatu dla zdrowia człowieka, cz. 2. Raport dla Instytutu Ochrony Srodowiska - PIB w ramach projektu „Opracowanie i wdrożenie Strategicznego Planu Adaptacji dla sektorów i obszarów wrażliwych na zmiany klimatu - KLIMADA".

BŁAŻEJCZYK K., BŁAŻEJCZYK A., BARANOWSKI J., 2014. Wieloletnia zmienność niektórych chorób klimatozależnych $w$ Polsce $i$ jej zwiazek $z$ wa runkami klimatycznymi. Prace i Studia Geograficzne 56, 37-65.

BŁAŻEJCZYK K., BARANOWSKI J., BŁAŻEJCZYK A., 2015. Wptyw klimatu na stan zdrowia $w$ Polsce: stan aktualny oraz prognoza do 2100 roku. Wyd. Akademickie SEDNO.

BŁAŻEJCZYK K., BŁAŻEJCZYK A., BARANOWSKI J., KUCHCIK M., 2020. Assessment of mortality risk in Poland due to cold and heat stress and predictions to 2100. J. Climate Change Res. $1,67-75$

CONFAlONieri U., MENNe B., AKHTAR R., EBI K.L., HaUengue M., Kovats R. S., Revich B., WoODWARD A., 2007. Human health. [W:] Climate Change 2007. Impacts, Adaptation and Vulnerability. Contribution of Working Group II to the Fourth Assessment Report of the Intergovernmental Panel on Climate Change. PARRY M. L., CANZIANI O. F., PALUTIKOF J.P., VAN DER Linden P. J., HANSON C. E. (red.). Cambridge University Press, Cambridge, UK, 391-431.

DESSAI S., 2002. Heat stress and mortality in Lisbon. Part I. Model construction and validation. Int. J. Biometeorol. 47, 6-12. 
DiAZ J., LinARES C., TOBIAS A., 2006. Impact of extreme temperatures on daily mortality in Madrid (Spain) among the 45-64 age-group. Int. J. Biometeorol. 50, 342-348.

EBI K., 2015. Health in the new scenarios for climate change research. Int. J. Environ. Res. Publ. Health 11, 30-46.

ENG H., MERCER J., 1998. Seasonal variations in mortality caused by cardiovascular diseases in Norway and Ireland. J. Cardiovasc. Risk 5, 89-95.

FERS J. P., 1995. Crises d'épilepsie et facteurs météorologiques dans le Finistère (Epilepsy crises and meteorological facts in Finistere). Climat et Santé 13, 57-74.

Gosling S. N., MCGREGOR G. R., PÁldy A., 2007. Climate change and heat related mortality in six cities Part 1: model construction and validation. Int. J. Biometeorol. 51, 525-540.

Gosling S. N., MCGREGOR G. R., LOwE J. A., 2009. Climate change and heat-related mortality in six cities Part 2: climate model evaluation and projected impacts from changes in the mean and variability of temperature with climate change. Int. J. Biometeorol. 53, 1-51.

GYLLERUP S., 1998. Cold climate and regional variation in coronary mortality in Sweden. [w:] Problems with cold work. HOLMÉR I., KUKLANE K. (red.). Arbete och hälsa, 18, 197-200.

Haines A., Kovats R. S., CAMPBELl-LENDRUM D., CORVALAN C., 2006. Climate change and human health: Impacts, vulnerability and public health. Publ. Health 120, 585-596.

KALKSTEIN L. S., 1998. Climate and human mortality: relationships and mitigating measures. Adv. Bioclimatol. 5, 161-177.

Keatinge W. R., Donaldson G. C., 1998. Differences in cold exposures associated with excess winter mortality. [W:] Problems with cold work. HOLMÉR I., KUKLANE K. (red.). Arbete och hälsa, 18, 210-215.

KIEĆ-ŚWIERCZYŃSKA M., KRECISZ B, 2008, Fotoalergia. [w:] Alergologia zawodowa. PAŁCZYŃSKI C., KIEĆ-ŚWIERCZYŃSKA M., WALUSIAK J. (red.). Oficyna Wydawnicza Instytutu Medycyny Pracy im. prof. J. Nofera, Łodź, 51-161.

KOZŁOWSKA-SZCZESNA T., BŁAŻEJCZYK K., 2010. Wpływ środowiska atmosferycznego na społeczeństwo jako przedmiot badań biometeorologii społecznej. Przeglad Geograficzny 82, 5-48.

KOZŁOWSKA-SZCZESNA T., KRAWCZYK B., KUCHCIK M., 2004. Wpływ środowiska atmosferycznego na zdrowie $i$ samopoczucie człowieka. IGiPZ PAN, Monografie 4, Warszawa.

KUCHCIK M., 2003. Topoclimatic conditions at various urban structures in Warsaw. Acta Universitatis Wratislaviensis, 2542, Studia Geograficzne $75,505-514$.

KuchciK M., 2006. Fale upałów $w$ Polsce $w$ latach 1993-2002, Przegląd Geograficzny, 78, 3, 397-412.

KUCHCIK M., 2017. Zmiany warunków termicznych $w$ Polsce na przełomie XX $i$ XXI wieku ich wpływ na umieralność. Prace Geograficzne IGiPZ, 263.

KUCHCIK M., BŁAŻEJCZYK K., 2001. Wpływ warunków pogodowych na zachorowalność i umieralność mieszkańców Warszawy. [W:] Badania środowiska fizycznogeograficznego $w$ aglomeracji warszawskiej. KRAWCZYK B., WECEAWOWICZ G. (red.) Prace Geograficzne 180, 71-87.
LAAIDI M., LAAIDI K., BESANCENOT J.-P., 2006. Temperature-related mortality in France, a comparison between regions with different climates from the perspective of global warming. Int. J. Biometeorol. 51, 145-153.

LASCHEWSKI G., JENDRITZKY G., 2002. Effects of the thermal environment on human health: an investigation of 30 years of daily mortality data from SW Germany. Climate Res. 21, 91103.

LINDGREN E., JAENSON T., 2006. Lyme boreliosis in Europe: influences of climate and climate change, epidemiology, ecology and adaptation measures. WHO Regional Office for Europe, Copenhagen, Denmark.

LITYŃSKA Z., ŁAPETA B., WOLSKA H., 2001. Index UV a człowiek. IMGW, Warszawa.

Lucas R., MCMichael T., SMith W., ARMSTRONG B., 2006. Solar ultraviolet radiation, global burden of disease from solar ultraviolet radiation, environmental burden of disease series, No. 13. WHO, Public Health and the Environment, Geneva.

MATZARAKIS A., MAYER H., 1991. The extreme heat wave in Athens in July 1987 from the point of view of human biometeorology. Atmosph. Environ. 25B, 203-211.

MCGREGOR G. R., 2001. The meteorological sensitivity of ischaemic heart disease mortality events in Birmingham, UK. Int. J. Biometeorol. $45,133-142$.

Meenl G. A., Stocker T. F., Collins W. D., Friedlingstein P., Gaye A. T., GRegory J. M., KITOH A., KNUTTI R., MuRPHY J. M., NODA A., RAPER S. C. B., WATTERSON I. G., WEAVER A. J., ZHAO Z. C., 2007. Global climate projections. [W:] Climate Change 2007: The Physical Science Basis. Contribution of Working Group I to the Fourth Assessment Report of the Intergovernmental Panel on Climate Change. SoloMON S., QIN D., MANning M., Chen Z., MARouis M., AVERYT K. B., TignoR M., Miller H. L. (red.). Cambridge University Press, Cambridge, United Kingdom and New York, NY, USA, 747-846.

MENNE B., APFEL F., Kovats S., RACIOPPI F., 2008. Protecting health in Europe from climate change. WHO Regional Office for Europe, Copenhagen, Denmark.

NAKICENOVIC N., AlCAMO J., DAVIS G., DE VRIES B., FEnhanN J., GafFin S., GREgORY K., GRIIBLER A., JUNG T.Y., KRAM T., LA ROVERE E. L., Michaelis L., Mori S., Morita T., Pepper W., Pitcher H., Price L., Riahi K., Roehrl A., ROGNER H.-H., SANKOVSKI A., SCHLESINGER M., SHUKLA P., SMITH S., SWART R., VAN ROOIJEN S., Victor N., DAdi TodeA D. A., 2000. Special report on Emissions Scenarios. A Special Report of Working Group III of the Intergovernmental Panel on Climate Change. Cambridge University Press,

PATERSON J., BERRY P., EBI K., VARANGU L., 2014. Health care facilities resilient to climate change impacts. Int. J. Environ. Res. Publ. Health $11,13097-13116$.

WHO, 2009. Improving public health responses to extreme weather/heat-waves - EuroHEAT. Technical report, 2009, WHO Regional Office for Europe, Copenhagen, Denmark. 
KOSMOS Vol. 70, 4, 597-610, 2021

ANNA BEAŻEJCZYK ${ }^{1}$, JAROSŁAW BARANOWSKI ${ }^{2}$

${ }^{1}$ Bioklimatologia, Laboratory of Bioclimatology and Environmental Ergonomics, 17/55 Eukowska Str., 04-133 Warszawa, ${ }^{2}$ Institute of Geography and Spatial Organization PAS, 51/55 Twarda Str., 00-818 Warszawa, E-mail: pracownia@bioklimatologia.pl, j.bar@twarda.pan.pl

\section{INFLUENCE OF CLIMATE CHANGES ON FLUCTUATIONS OF MORBIDITY AND MORTALITY DUE TO CLIMATE RELATED DISEASES IN POLAND IN $21^{\text {ST }}$ CENTURY}

\section{Summary}

Climate and its changes influence health status of individuals and societies. Health problems involved by climatic factors are called as climate related diseases (CRD). In Poland the most frequent CRD are: infections of respiratory tracts, influenza, skin cancers, Lyme boreliosis, salmonellosis, circulatory dysfunctions as well as dysfunctions of thermoregulatory system due to heat and cold stress. Epidemiological and climate data from the years 1973-2014 were the basis for statistical models of climate impacts on CRD. These models were applied to prediction of CRD mortality and morbidity in consecutive decades of $21^{\text {st }}$ century. We have found statistically significant increase of skin cancer and Lyme boreliosis morbidity as well as mortality due to circulatory and heat stress dysfunctions. However, decreasing trends were found for influenza infections and mortality due to respiratory problems.

Key words: climate change, climate related diseases, climate change predictions, morbidity predictions, Poland 